\title{
Clonal evaluation for early growth performance of Eucalyptus in South Gujarat, India
}

\author{
L. K. Behera*, D. P. Patel, R. P. Gunaga, A. A. Mehta and D.B. Jadeja \\ Department of Silviculture and Agroforestry, College of Forestry, Navsari Agricultural University, Navsari-396450 \\ (Gujarat), INDIA \\ *Corresponding author. E-mail: lkbehera@nau.in
}

Received: February 28, 2016; Revised received: July 21, 2016 Accepted: November 8, 2016

\begin{abstract}
This study was carried out in College of Forestry, Navsari Agricultural University, Navsari, Gujarat. Total 20 clones having age of $51 / 2$ years were selected for early growth evaluation at field condition. There was a significant variation $(\mathrm{P}<0.05)$ among 20 clones of Eucalyptus for growth parameters viz., tree height, $\mathrm{DBH}$, mid-diameter, form quotient and volume of standing tree. Tree height varied from 18.5 to $23.6 \mathrm{~m}$ with DBH range of 11.47 to 16.07 $\mathrm{cm}$. Mid-diameter indirectly helps to assess the tapering of tree and it ranged from 6.99 to $10.57 \mathrm{~cm}$ among 20 clones. The form quotient was used while calculation of volume of Eucalyptus clones. The form quotient varied between 0.58 and 0.71 with overall mean of 0.63 at studied site. Volume of standing tree ranged from 0.12 to $0.28 \mathrm{~m}^{3}$. The overall results showed that clones such as C12 (P2045), C17 (B2253), C4 (P413), C8 (P526), C7 (P498), C16 (SRO16) and C11 (P3020) performed superior for early growth attribute and stem form and these clones suggested for large scale plantation in South Gujarat region.
\end{abstract}

Keywords: Clone, DBH, Eucalyptus, Form quotient, Growth, Height, Volume

\section{INTRODUCTION}

Eucalypts is one of the fast growing tree species widely planted in the Tropics mainly for the purpose of pulp wood for paper and rayon. They are essentially Austro-Malayan trees with a natural latitudinal range extending from $7^{\circ} \mathrm{N}$ to $43^{\circ} 39^{\prime} \mathrm{S}$. It flourishes from coastal areas to areas situated at an altitude of $2000 \mathrm{~m}$, tropical to warm temperate climate and rainfall ranges of 400-4000 mm (Tewari, 1992). As a short rotation and fast growing nature, this species is widely preferred by farmers, where there is a great demand from pulp and paper industries as well as local market for pole (Saigal and Kashyap, 2002; Behera, 2016). Significant improvements in quality of produce and reductions in per unit production costs have also been possible with the use of true to type, uniform and genetically improved clonal planting stock of Eucalyptus (Lal, 2001). The demand of wood from forest or commercial plantation for timber, fuelwood, pulp and paper production is increasing year after year. Among many, Eucalyptus is widely planted in farm forestry system in the form of block plantations, boundary plantations, strip plantations and agroforestry systems throughout the world more particularly in India to provide wood products especially in the region of scarcity (Boland, 1980; Dogra and Sharma, 2003). India is one of the largest Eucalyptus growing countries with a total area of 1.36 million ha plantations up to 1999 (FSI, 1999), which is increased to around 8.00 mha up to 2010
(Aregowda et al., 2010). More than 65 Eucalyptus species and various provenances were tried to meet the various wood based demands of the country (Kulkarni, 2004 and 2008). The productivity of Eucalyptus varies from country to country with changing climatic, edaphic and topographic conditions. In Congo, Brazil and Papua New Guinea, clonal plantations of Eucalyptus have produced $80-90 \mathrm{~m}^{3} / \mathrm{ha} /$ year (Ugalde and Perez, 2001) whereas in Indian conditions, the productivity ranged from 6 to $10 \mathrm{~m}^{3} / \mathrm{ha} / \mathrm{yr}$ in seed route plantations (Lal, 1993) to 20 to $23 \mathrm{~m}^{3} / \mathrm{ha} / \mathrm{yr}$ in rainfed conditions and $50 \mathrm{~m}^{3} / \mathrm{ha} / \mathrm{yr}$ in clonal based managed farm plantations (Lal, 2001; Kulkarni, 2002), sometimes, it reached to $100 \mathrm{t} /$ ha in pulp wood plantation (Kulkarni, 2014). The present study was undertaken to evaluate the different clones of Eucalyptus in South Gujarat conditions, India for further their selection and multiplication.

\section{MATERIALS AND METHODS}

The present trial was carried at the instructional farm of College of Forestry, Navsari Agricultural University, Navsari. The plantation was established during September 2009 consists of 20 clones planted at 2 x $2 \mathrm{~m}$ spacing in three replications following Randomized Block Design (RBD). For the present study, total nine ramets per clone (3 ramets $x 3$ replications) were selected randomly and various growth parameters such as Diameter at Breast Height (DBH), mid- diameter, tree height were recorded at the age of $5 \frac{1}{2}$ years fol- 
lowing Chaturvedi and Khanna (2000). DBH was measured $1.37 \mathrm{~m}$ from ground level using Mantax Blue Caliper whereas mid-point diameter (middiameter) was measured at the mid-point (i.e., half of the height of tree) by using 1000 Criterion Dendrometer and total height of tree was measured from ground to the tip of the leading shoot by using Electronic Clinometer. Form quotient (FQ) was calculated by formula given by Schiffel (1899). Similarly, volume was also calculated following Panwar and Bhardwaj (2005) and Qunekham (2009). The experimental data were subjected to the statistical analysis as per the procedure suggested by Gomez and Gomez (1984) using RBD.

\section{RESULTS AND DISCUSSION}

Clonal variation for growth parameters such as DBH, mid- diameter, height, form quotient and volume was recorded and it was significantly differ among 20 clones of Eucalyptus. Results showed that DBH varied between 11.47 and $16.07 \mathrm{~cm}$ with an overall mean of $13.28 \mathrm{~cm}$ (Table 1). Maximum DBH was attained by clone $\mathrm{C} 4$ which was statistically at par with clones $\mathrm{C} 17, \mathrm{C} 12, \mathrm{C} 8, \mathrm{C} 11$ and $\mathrm{C} 7$. Variation among clones in growth parameter may be due to genetic make-up and interactions with the environmental factors. Kumar et al. (2010) reported significant variation among clones of E. tereticornis for DBH at the age of 5.5 years, where as Dhillon and Singh (2010) also found difference in diameter growth among clones of E. tereticornis Sm. at the age of 3.5 years. Luna and Singh (2009) also studied clonal variation for growth parameters including DBH among 12 clones of Eucalyptus tested at Ludhiana. Such kind of variation would be helpful in selection of superior clones to the region for multiplication and plantation purposes to obtain higher biomass and economic returns. Lal et al. (2006) identified best clones out of $36 \mathrm{viz}$., clone 2070, 285, 316, 288, 498, 286 and 2045 for Punjab ecological condition.

Significant variation among clones for tree height was recorded and it varied from 18.5 to $23.6 \mathrm{~m}$ (Table 1 ). Clones viz., C17, C8, C12, C7, C15, C4, C18, C11 and C6 showed better tree height than other clones. This variation may be due to genetic factor, where all these clones are grown in a small piece of land having similar environmental condition. Such genetic based improvement would be ideal for selection of superior genotypes for further multiplication and afforestation programme in similar environmental condition. Such report is also recorded by several researchers in different eucalyptus species. Lal et al. (1997) reported that clone number 6 proved to be the best among all the 20 clones of Eucalyptus and exhibited maximum height of $23 \mathrm{~m}$ at 7 years age. Similarly, Lal et al. (2006) evaluated growth performance of 36 clones of Eucalyptus and clone 2070 performed best with maximum mean height of $16.29 \mathrm{~m}$ as compared to other clones at the age of 4 years. Luna and Singh (2009) studied the growth performance of 12 clones of Eucalyptus at Ludhiana. Clones bearing no. 413 and 2070 recorded significantly higher height growth as compared to other clones. Kumar et al. (2010) evaluated different clones of Eucalyptus tereticornis for different growth characters including tree height. Further, they identified Clone 3 and Clone 37 as a superior genotypes than

Table 1. Clonal variation in tree height, DBH and mid-diameter among 20 clones of Eucalyptus.

\begin{tabular}{|c|c|c|c|}
\hline Clones & Tree height (m) & DBH (cm) & Mid-diameter (cm) \\
\hline $\mathrm{C}_{1}: \mathrm{P} 72$ & 20.50 & 13.40 & 8.76 \\
\hline $\mathrm{C}_{2}: \mathrm{P} 1$ & 20.07 & 11.47 & 7.18 \\
\hline $\mathrm{C}_{3}: \mathrm{P} 405$ & 18.53 & 11.47 & 7.21 \\
\hline $\mathrm{C}_{4}: \mathrm{P} 413$ & 22.00 & 16.07 & 9.85 \\
\hline $\mathrm{C}_{5}: \mathrm{P} 411$ & 20.13 & 13.13 & 8.07 \\
\hline $\mathrm{C}_{6}: \mathrm{P} 316$ & 21.40 & 13.40 & 8.38 \\
\hline $\mathrm{C}_{7}: \mathrm{P} 498$ & 22.13 & 14.23 & 9.29 \\
\hline $\mathrm{C}_{8}: \mathrm{P} 526$ & 22.53 & 14.67 & 9.38 \\
\hline $\mathrm{C}_{9}: \mathrm{P} 2136$ & 20.07 & 12.23 & 7.31 \\
\hline $\mathrm{C}_{10}: \mathrm{P} 2155$ & 20.57 & 12.03 & 6.99 \\
\hline $\mathrm{C}_{11}: \mathrm{P} 3020$ & 21.57 & 14.30 & 8.92 \\
\hline $\mathrm{C}_{12}: \mathrm{P} 2045$ & 22.43 & 14.97 & 10.57 \\
\hline $\mathrm{C}_{13}: \mathrm{P} 2069$ & 20.50 & 11.47 & 7.58 \\
\hline $\mathrm{C}_{14}: \mathrm{JK} 08$ & 20.73 & 12.90 & 8.01 \\
\hline $\mathrm{C}_{15}: \mathrm{JK} 02$ & 22.20 & 12.40 & 7.31 \\
\hline $\mathrm{C}_{16}: \mathrm{SRO} 16$ & 20.73 & 14.23 & 8.98 \\
\hline $\mathrm{C}_{17}: \mathrm{B} 2253$ & 23.60 & 15.23 & 9.87 \\
\hline $\mathrm{C}_{18}: \mathrm{B} 2153$ & 22.00 & 12.97 & 8.20 \\
\hline $\mathrm{C}_{19}: \mathrm{B} 271$ & 20.47 & 11.97 & 7.67 \\
\hline $\mathrm{C}_{20}: \mathrm{B} 288$ & 20.37 & 13.07 & 9.22 \\
\hline Mean (C) & 21.13 & 13.28 & 8.44 \\
\hline $\operatorname{SEm}( \pm)$ & 0.80 & 0.88 & 0.60 \\
\hline CD@ $9.0 \%$ & 2.28 & 2.51 & 1.70 \\
\hline $\mathrm{CV}(\%)$ & 6.52 & 11.44 & 12.22 \\
\hline
\end{tabular}


Table 2. Clonal variation in Form quotient and volume among the clones of Eucalyptus.

\begin{tabular}{lcc}
\hline Clones & Form quotient & Volume $\mathbf{( m}^{\mathbf{3}} \mathbf{)}$ \\
\hline $\mathrm{C}_{1}: \mathrm{P} 72$ & 0.65 & 0.19 \\
$\mathrm{C}_{2}: \mathrm{P} 1$ & 0.62 & 0.14 \\
$\mathrm{C}_{3}: \mathrm{P} 405$ & 0.63 & 0.12 \\
$\mathrm{C}_{4}: \mathrm{P} 413$ & 0.61 & 0.27 \\
$\mathrm{C}_{5}: \mathrm{P} 411$ & 0.61 & 0.17 \\
$\mathrm{C}_{6}: \mathrm{P} 316$ & 0.62 & 0.19 \\
$\mathrm{C}_{7}: \mathrm{P} 498$ & 0.65 & 0.23 \\
$\mathrm{C}_{8}: \mathrm{P} 526$ & 0.64 & 0.24 \\
$\mathrm{C}_{9}: \mathrm{P} 2136$ & 0.60 & 0.14 \\
$\mathrm{C}_{10}: \mathrm{P} 2155$ & 0.58 & 0.14 \\
$\mathrm{C}_{11}: \mathrm{P} 3020$ & 0.62 & 0.22 \\
$\mathrm{C}_{12}: \mathrm{P} 2045$ & 0.71 & 0.28 \\
$\mathrm{C}_{13}: \mathrm{P} 2069$ & 0.66 & 0.14 \\
$\mathrm{C}_{14}: \mathrm{JK} 08$ & 0.62 & 0.17 \\
$\mathrm{C}_{15}: \mathrm{JK} 02$ & 0.59 & 0.16 \\
$\mathrm{C}_{16}: \mathrm{SRO} 16$ & 0.63 & 0.21 \\
$\mathrm{C}_{17}: \mathrm{B} 2253$ & 0.65 & 0.28 \\
$\mathrm{C}_{18}: \mathrm{B} 2153$ & 0.63 & 0.19 \\
$\mathrm{C}_{19}: \mathrm{B} 271$ & 0.64 & 0.15 \\
$\mathrm{C}_{20}: \mathrm{B} 288$ & 0.71 & 0.20 \\
$\mathrm{Mean}(\mathrm{C})$ & 0.63 & 0.19 \\
$\mathrm{SEm}$ ( $)$ CD & 0.014 & 0.028 \\
$\mathrm{CD}$ 5.0 $\%$ & 0.041 & 0.079 \\
$\mathrm{CV}$ (\%) & 3.93 & 24.82 \\
\hline
\end{tabular}

others. Gangwar et al. (2015) identified Clone AP10 of Eucalyptus as the best clone among the studied ones based on height. Such genetic based variation is highly suitable for further selection and multiplication.

Mid-diameter measurement is required to determine the rate of taperness of stem and that influences the final quantity of volume. Therefore, mid-diameter help to minimize the error while calculating stem volume. Taper is closely related to the growing space available to the individual tree and is extremely high for solitaries. Similarly, form quotient is also help in precise the tree volume. In the study, both mid-diameter and form quotient showed significant variation among 20 clones. Mid-diameter varied from 6.99 to $10.57 \mathrm{~cm}$ among 20 clones (Table 1). Clones such as $\mathrm{C} 4$, followed by $\mathrm{C} 17$, $\mathrm{C} 8, \mathrm{C} 7, \mathrm{C} 20, \mathrm{C} 16$ and $\mathrm{C} 11$ recorded highest values for mid diameter as compared to other clones. It indicates that higher mid diameter representing lower taperness or near to the cylindrical shape that indirectly indicating more biomass. Moreover, form quotient value ranged from 0.58 to 0.71 among 20 clones, where clones such as $\mathrm{C} 12$ and $\mathrm{C} 20$ exhibited more of cylindrical bole form having FQ value $>0.70$. However, other 10 remaining clones showed FQ values $>0.65$ (Table 2). Stem-form varied among several factors including form quotient (Mu-hairwe et al., 1994). Age of the tree, growing habitat, tree density, slope are major factors that influences the FQ (Chaturvedi and Khanna, 1982; Husch et al., 2003). For instance stand density (Sharma and Par-ton, 2009), thinning (Sharma et al., 2002), pruning (Valenti and Cao, 1986), water availability (Wiklund et al., 1995) and supply of other re- sources (Socha and Kulej, 2007) influences the FQ values. However, variation among clones for FQ could be due to genetic factor, where all the clones were grown under uniform condition (Gomat et al., 2011). Volume of standing tree varied between $0.12 \mathrm{~m}^{3}$ and $0.28 \mathrm{~m}^{3}$. Clones such as $\mathrm{C} 12, \mathrm{C} 17, \mathrm{C} 4$ and $\mathrm{C} 8$ showed better performance as compared to other clones for volume (Table 2). Such kind of variation was also recorded among clones of Eucalyptus by different scientist all over India. Lal et al. (2006) evaluated 36 clones of Eucalyptus for volume and clone 2070 performed better with volume of $121.594 \mathrm{~m}^{3} /$ ha than other clones within a period of 4 years. Luna and Singh (2009) also recorded variation among 12 clones of Eucalyptus for volume at the age of 3 years. It is found that, among 12 clones, clone 413 recorded maximum volume (over bark volume of $86.41 \mathrm{~m}^{3} /$ ha and under bark of volume $70.47 \mathrm{~m}^{3} / \mathrm{ha}$ ). Vennila et al. (2011) reported that Eucalyptus clones viz., EC MTP 48, EC MTP 47 and EC MTP 41 recorded superiority for growth including volume at the age of 8 months than other clones. Similarly, Gangwar et al. (2015) also recommended clone AP10 based on superiority of volume and other growth traits in eucalyptus for large scale plantation.

\section{Conclusion}

The present study concluded that all the 20 clones significantly varied for tree height, $\mathrm{DBH}$, mid-diameter, form quotient and volume. Clones such as C12 and $\mathrm{C} 17$ performed superior with respect to volume of tree $\left(0.28 \mathrm{~m}^{3}\right)$ and which were statistically at par with clones $\mathrm{C} 4, \mathrm{C} 8, \mathrm{C} 7, \mathrm{C} 16$ and $\mathrm{C} 11$. Therefore, these two clones $\mathrm{C} 12$ and $\mathrm{C} 17$ along with $\mathrm{C} 4, \mathrm{C} 8, \mathrm{C} 7, \mathrm{C} 16$ and $\mathrm{C} 11$ are recommended for large scale plantation programme in south Gujarat region.

\section{REFERENCES}

Aregowda, J., Prabhu, S.T. and Patil, R.S. (2010). Evaluation of botanicals and synthetic insecticides against Eucalyptus gall wasp, Leptocybe invasa (Eulophidae: Hymenoptera). Karnataka J. Agric. Sci., 23(1): 200-202

Behera, L.K. (2016). Clonal variation in physical, anatomical and chemical properties of wood of Eucalyptus. Ph.D. Thesis, Navsari Agricultural University, Navsari. Pp. 215

Boland, D.J. (1980). Eucalyptus seed for Indian plantations from better Australian natural seed sources. Indian Forester, 107(3): 125-134

Chaturvedi, A.N. and Khanna, L.S. (1982). Forest Mensuration. International Book Distributors, Dehra Dun.

Chaturvedi, A.N. and Khanna, L.S. (2000). Forest Mensuration and Biometry. Khanna Bandhu, Dehra Dun.

Dhillon, G.P.S and Singh, A. (2010). Variation in growth traits among progenies of Eucalyptus tereticornis Sm. under flood- plain conditions of Punjab. Indian $J$. Agroforestry, 12(1): 91-94

Dogra, A.S. and Sharma, S.C. (2003). Volume prediction equations for Eucalyptus hybrid in Punjab. Indian Forester, 129(12): 1451-1460 
FSI (1999). State of Forest Report. Survey of India, MoEF, Govt. of India, Dehra Dun.

Gangwar, P., Pandey, V and Tewari, B. (2015). Assessing productivity of eucalyptus clones under different edaphic conditions. Paripex - Indian Journal of Research, 4(8): 43-44

Gomat, H., Deleporte, P., Moukini, R., Mialounguila, G., Ognouabi, N., Saya, A., Vigneron, P. and Saint-Andre, L. (2011). What factors influence the stem taper of Eucalyptus: growth, environmental conditions, or genetics? Annals of Forest Science, 68: 109-120

Gomez, K.A. and Gomez, A.A. (1984). Statistical procedure for agricultural research ( $2^{\text {nd }}$ ed.). Johan Willey and Sons Inc. New York. 680 p.

Husch, B., Beers, T.W. and Kershaw, J.A.J. (2003). Forest Mensuration ( $4^{\text {th }}$ Edition), John Wiley \& Sons, Inc., New Jersey.

Kulkarni, H.D. (2002). Bhadrachalam clones of eucalyptusan achievement of ITC. Paper presented at the IUFRO Science/ Policy interface Task Force regional meeting held in Chennai, India, 13- 16 July

Kulkarni, H.D. (2004). Clonal forestry for industrial wood production. An ITC experience. In: Compendium on Clonal forestry. Ed. Parthiban K.T., Forest College and Research Institute, Tamil Nadu Agriculture University, Mettupalyam, India, pp-92-113.

Kulkarni, H.D. (2008). Private farmer- private industry partnerships for industrial wood production: a case study. International Forest Rev., 147- 155

Kulkarni, H.D. (2014). Industrial agroforestry: An ITC initiative. Indian Farming, 63(11): 42-44

Kumar, R.; Bangarwa, K.S. and Desai, A.K. (2010). Studies on evaluation of different Eucalyptus tereticornis Sm. clones. Indian J. Agroforestry, 12(1): 49-52

Lal, P. (1993). Improving land productivity and returns from agroforestry plantations. Indian Forester, 119(6): 431440

Lal, P. (2001). Private sector forestry research: a success story from India. Bois Et Forets Des Tropiques, 267(1): 33-48

Lal, P., Dogra, A.S., Sharma, S.C. and Chahal, G.B.S. (2006). Evaluation of different clones of Eucalyptus in Punjab. Indian Forester, 132(11): 1383-1390

Lal, P., Kulkarni, H.D., Srinivasa, K., Venkatesh, K.R. and Santhakumar, P. (1997). Genetically improved clonal planting stoc of Eucalyptus- A success story from India. Indian Forester, 123: 1117-1138

Luna, R.K. and Singh, B. (2009). Estimates of genetic variability and correlation in Eucalyptus hybrid progeny for early selection. Indian Forester, 135(2): 147-160
Muhairwe, C., Lemay, V. and Kozak, A. (1994). Effects of adding tree, stand, and site variables to Kozaks variableexponent taper equation. Canadian Journal of Forest Research, 24: 252-259

Panwar, P. and Bhardwaj, S.D. (2005). Handbook of Practical Forestry. Agrobios (India), Jodhpur, India, pp-191.

Qunekham, K. (2009). Developing volume and taper equations for Styrax tonkinensis in Laos. M.Sc. (Forestry) thesis submitted to University of Canterbury, New Zealand.

Saigal, S. and Kashyap, D. (2002). Review of companyfarmer partnership for the supply of raw material to wood-based industry. Ecotech Services, New Delhi, pp$10-96$

Schiffel, A. (1899). Form and Inhalt der Fichte (Form and volume of spruce). Mitt. Forstl.Versuchsanst. Osterreiche 24.

Sharma, M. and Parton, J. (2009). Modeling stand density effects on taper for jack pine and black spruce plantations using dimensional analysis. Forest Science, 55: 268282

Sharma, M.; Oderwald, R. and Amateis, R. (2002). A consist -ent system of equations for tree and stand volume. Forest Ecology and Management, 165: 183-191

Socha, J. and Kulej, M. (2007). Variation of the tree form factor and taper in European larch of Polish provenances tested under conditions of the Beskid Sadecki mountain range (Southern Poland). J. For. Sci., 53(12): 538-547

Tewari, D.N. (1992). Monograph on Eucalyptus. Surya Publication, Dehradun. pp. 361

Ugalde, L. and Perez, O. (2001). Mean annual volume increment of selected industrial forest plantation species. Forest Plantation Thematic Papers, Working Paper 1. Forest Resources Development Service, Forest Resources Division, FAO, Rome.

Valenti, M.A. and Cao, Q.V. (1986). A comparison of the effects of one-step and two-step pruning on loblolly pine stem form. Southern Journal of Applied Forestry, 10: $251-253$

Vennila, S., Parthiban, K.T., Seenivasan, R., Saravanan, V., Anbu, P.V., Kanna, S.U. and Durairasu, P. (2011). Pulpwood characterization and screening short rotation Eucalyptus clones. Indian Journal of Ecology, 38 (Special Issue): 84-90

Wiklund, K., Konopka, B. and Nilsson, L. (1995). Stem form and growth in Picea abies L: Karst in response to water and mineral nutrient availability. Scandinavian Journal of Forest Research, 10: 326-332 